\title{
ECONOMIC NATIONALISM: US TRADE POLICY VS. BREXIT
}

\author{
STEVE MCCORRISTON ${ }^{*}$ ANd IAN M. SHELdoN ${ }^{* *}$
}

\begin{abstract}
In 2016, both the election of President Trump and the UK's vote to leave the European Union represented important shifts in the approach of both countries to their international trading relationships. In the case of the US, the Trump administration has sought to target tariffs against countries such as China, while the UK is seeking to exit a highly integrated market and also assert its sovereignty. In this article, it is shown that both events were a response to the China import shock, which in turn led to a dramatic rise in populism resulting in a substantive shift in each country's trade policy, each generating substantive actual and expected economic costs. However, the policy responses to populism are quite different: the US has chosen to be explicitly protectionist, a feature of economic nationalism, while the UK is not seeking to raise trade barriers as it adjusts its trading arrangements. Nonetheless, both countries are following a path of economic "dis-integration," the US undermining its multilateral obligations under the WTO, the UK seeking to leave the European Union of which it has been a member since 1973.
\end{abstract}

\footnotetext{
* Professor of Agricultural Economics, University of Exeter Business School, Exeter, UK.

** Andersons Chair of Agricultural Marketing, Trade and Policy, Department of Agricultural, Environmental, and Development Economics, The Ohio State University, Columbus, Ohio, US.
} 


\section{INTRODUCTION}

The world trading system currently faces two major challenges: the first is President Trump's ongoing trade war with China, and other targeted countries such as Japan; ${ }^{1}$ the second is the UK's exit, in some form, from the European Union (EU), commonly referred to as "Brexit." 2 While apparently related to quite different issues, there are clear similarities between escalation of the trade war by the current US administration and the UK's departure from the EU. One similarity relates to the underlying drivers that contributed in 2016 to the election of Donald Trump and the majority decision in the UK referendum to leave the EU: each of these can be tied to the rapid growth in globalization in the last two decades following China's entry to the World Trade Organization (WTO) in 2001. ${ }^{3}$ In addition, issues arising from the China import shock were then exacerbated in the aftermath of the 2008 global financial crisis, notably the lack of a comprehensive US social safety net and the deliberate policy of economic austerity adopted by the UK government, which contributed to the measured increase in economic inequality in both countries. ${ }^{4}$

At the same time, careful interpretation of the apparently different policy choices of the US and UK also points to other underlying similarities. Common to both the US and UK is the derogation of current international and regional trading commitments and the desire to "take control" of national trade policies. ${ }^{5}$ In the case of the US, recent trade policy developments have focused on reducing adherence to multilateral trade rules and targeting specific countries

\footnotetext{
' See Meredith A. Crowley, Introduction to TRADE WAR: THE ClaASH OF ECONOMIC Systems Endangering Global Prosperity, I (Meredith A. Crowley ed., 2019) (ebook), https://voxeu.org/content/trade-war-clash-economic-systems-threateningglobal-prosperity.

${ }^{2}$ See Thomas Sampson, Brexit: The Economics of International Disintegration, 31 J. ECON. Pierspectives 163, 163 (2017).

${ }^{3}$ See David H. Autor et al., The China Syndrome: Local Labor Market Effects of Import Competition in the United States, 103 AM. ECON. REV. 2121, 2121-22 (2013); see Italo Colantone \& Piero Stanig, Global Competition and Brexit, 112 AM. POL. SCl. Rivv. 201, 201 (2018).

${ }^{4}$ See Pol Antràs et al., Globalization, Inequality and Welfare, 108 J. INT'L. ECON. 387, 387 (2017); Dani Rodrik, Populism and the Economics of Globalization, $1 \mathrm{~J}$. INr'I. BuS. POLICY 12, 16-18 (2018).

${ }^{5}$ See Csongor István Nagy, World Trade, Imperial Fantasies and Protectionism: Can You Really Have Your Cake and Eat It Too?, 26 IND. J. GLOBAL. LEGAl. STUD., 87, 87-89 (2019).
} 
with tariffs, even if the consequence of this is to provoke a global trade war. ${ }^{6}$ The UK's departure from the EU is also predicated on national sovereignty issues: the unwillingness to be bound by EU rules and the desire to establish its own free trade agreements (FTAs). ${ }^{7}$ Both cases involve disengagement from arrangements that have been longstanding; and both will have consequences for other countries and, despite the rhetoric concerning the expected gains associated with economic nationalism, both the US and UK will likely face significant economic losses, as a consequence of these decisions.

One important difference between economic assessments of the US trade war with China and the UK's departure from the EU is that the former is associated with de-globalization as reflected in President Trump's labeling of US trade decisions as "America First.", In contrast, supporters of Brexit, and UK politicians leading the debate over Brexit, have never claimed to be against globalization; indeed, the desire to seek new trade agreements post-departure from the EU is testament to a desire to promote trade with non-EU countries and also to have an acceptable post-Brexit trade agreement with the EU. ${ }^{9}$ The paradox of this position is that the UK is leaving the world's largest trading bloc, where UK trade with EU countries accounts for, by far, the most important source and destination for its imports and exports, intra-EU trade being facilitated by zero border tariffs and common standards. Therefore, on face value, while current US and UK trade policy choices appear different, and notwithstanding the nuances, there are common themes relating to both the underlying drivers and the likely consequences of these policy choices.

The aim of this article is to explore the issue of economic nationalism as reflected in the trade policy decisions being made by both the US and UK. Part II of the article focuses on the logic of economic nationalism and its connection to populism, while in Part III

\footnotetext{
${ }^{6}$ See Aaditya Mattoo \& Robert W. Staiger, Trade Wars: What Do They Mean? Why are They Happening Now? What are the Costs? 2 (World Bank Grp., Working Paper No. 8829, 2019).

${ }^{7}$ See Jennifer Johns, Britain Fails to Understand the Nature of Globalization at its Peril, THE CONVERSATION (Aug. 5, 2016), https://theconversation.com/ britainfails-to-understand-the-nature-of-globalisation-at-its-peril-61392.

${ }^{8}$ See Charles Hankla, What Does "America First" Mean for American Economic Interest?, THE CONVERSATION (Feb. 1, 2017), https:// theconversation.com/whatdoes-america-first-mean-for-american-economic-interests-71931.

${ }^{9}$ See Iain Mansfield, A Blueprint for Britain: Openness not Isolation, INST. FOR ECON. AFF., 3 (2014), https://www.iea.org.uk/sites/default/files/publications /files/Brexit\%20Entry\%2 0170 final_bio_web.pdf.
} 
of the article we explore the commonality of the China import shock as it has affected the US and UK economies. Then in Part IV, we sketch out the economic response of both the US and UK; while the nature of response is clearly more definitive in the case of the US, given that President Trump has already initiated the imposition of tariffs, in the case of the UK, the possible choices, such as they are at the time of writing, are still on the table awaiting the political process to reach a conclusion. We survey recent assessments of the costs of trade policy choices made by the US and (still to be made) by the UK in Part V of the article, which is then followed by a summary and some concluding remarks in Part VI.

\section{The Logic Of ECONOMIC NATIONALISM}

As we discuss in detail in Section III, trade liberalization and more broadly globalization can create both economic winners and losers, i.e., consumers and resources employed in the exportcompeting sectors of an economy gain while resources such as lessskilled labor employed in the import-competing sectors of an economy suffer the costs of job displacement and reduced incomes. ${ }^{10}$ From the perspective of cost-benefit analysis, it is straightforward to demonstrate the gains from trade by appealing to the so-called KaldorHicks compensation principle. Specifically, as long as benefits of trade liberalization outweigh the losses, in principle it is possible for the winners to compensate the losers and still be better off, i.e., there is the potential for a Pareto improvement whereby some agents in the economy are made better off without the remaining agents being made any worse off. ${ }^{11}$

The obvious problem with this principle is highlighted when compensation of the losers is either insufficient or does not actually occur. As we will argue in the remainder of the Section, this creates the potential for populism to gain ground, the political outcome being economic nationalism, i.e., opposition to free trade and increased isolationism, reduction of the welfare state through laissez faire domestic economic policies, and a strong nationalist stance. ${ }^{12}$

\footnotetext{
${ }^{10}$ See Rodrik, supra note 4, at 17-18.

1 See Antràs et al., supra note 4 , at 388 .

${ }^{12}$ See Italo Colantone \& Piero Stanig, The Trade Origins of Economic

Nationalism: Import Competition and Voting Behavior in Western Europe, 62 AM.

J. Pol.. SCı. 936, 936 (2018).
} 
Given the extent of trade liberalization and globalization in the post-war period, an obvious question is why did economic nationalism not appear earlier in developed economies? The answer to this has been widely discussed in the political science literature. Essentially, developed countries in the Organization for Economic Cooperation and Development (OECD) absorbed two key lessons from the interwar period: first, protectionist trade policies had the potential to undermine the world trading system, hence the commitment to multilateral governance of that system through the General Agreement on Tariffs and Trade (GATT); and second, this commitment came with the recognition by policymakers that they had to manage support for free trade by spending on the welfare state as a means of protecting their citizens from the distributional impact of economic openness. ${ }^{13}$

John Ruggie has termed this tradeoff as "embedded liberalism," 14 and even though it took different forms across the OECD, the bargain was based on the expectation of citizens that their governments would limit the costs and redistribute the benefits of free trade via some kind of government intervention and spending. Support for this hypothesis points to empirical evidence for openness to trade being correlated with higher levels of public spending, ${ }^{15}$ as well public support for free trade being correlated with higher welfare spending among OECD countries. ${ }^{16}$

However, as Harvard economist Dani Rodrik has pointed out, the compensation required to satisfy the bargain of "embedded liberalism" is costly. ${ }^{17}$ A key feature of advanced globalization is that as capital has become more mobile, it has resulted in erosion of the tax base of countries seeking to supply social insurance. The alternative of increasingly progressive income taxation has significant adverse economic effects on labor, which is also unappealing politically. ${ }^{18}$ Due

${ }^{13}$ See Jude C. Hays et al., Government Spending and Public Support for Trade in the OECD: An Empirical Test of the Embedded Liberalism Thesis, 59 INT'L ORG. 473, 473-74 (2005).

${ }^{14}$ See John G. Ruggie, International Regimes, Transactions, and Change:

Embedded Liberalism in the Postwar Economic Order, 36 INT'L ORG., 379, 392 (1982).

${ }^{15}$ See Dani Rodrik, Why Do More Open Economies Have Bigger Governments?, 106 J. POL. ECON. 997, 997-99 (1998).

${ }^{16}$ See Hays et al., supra note 13, at 488-91.

${ }^{17}$ See Dani Rodrik, Has Globalization Gone Too Far?, 39 CAL. MGMT. REV. 29, 33 (1997).

${ }^{18}$ See id:; Antràs et al., supra note 4 , at 407. 
to fiscal constraints, the welfare state in many OECD countries began to be cut back in the 1980s, resulting in insufficient compensation to losers from globalization and a loss of credibility in "embedded liberalism." 19

As redistribution policies have become less feasible, and the costs of redistribution have increased due to the severity of the China import shock, "embedded liberalism" has the potential to be replaced by economic nationalism. ${ }^{20}$ The mechanism for compensating losers from globalization switches to protectionism. A corollary of this is that spending on social insurance can be further reduced, which is a popular choice with higher-income taxpayers. These policies then get wrapped up in a political narrative of authoritarian nationalism drawing on populist grievances. ${ }^{21}$ Before looking at what specifically drove the US and UK to some form of economic nationalism, it is useful to think about what might result in some portion of a country's polity being attracted to populist themes, and why that might translate into a concern about that country's trading arrangements.

Populism can be defined as a political movement that involves a combination, but not necessarily all, of anti-elitism, authoritarianism and nativism, as well as opposition to liberal economics and globalization. ${ }^{22}$ A key to populism is that society is seen as being divided into two groups: the people and the elite, the latter controlling government, business and the financial sector, who are perceived as not acting in the best interests of the people. This idea was clearly captured in speeches made by Donald Trump both before and after his election as US president, as well as in the language of those supporting the campaign for the UK to leave the EU who sought to discredit the views of economists on the potential costs of Brexit as "project fear." 23 Populists believe that only they represent the "true people," and as a

\footnotetext{
${ }^{19}$ See Colantone \& Stanig, supra note 12, at 938; JuDE C. HAYS, GLOBAL.IZATION AND THI: NIEW POIITICS OF: EMBIEDDED LIBERAI.ISM, 12-13 (2009).

${ }^{20}$ See Colantone \& Stanig, supra note 12 , at 938.

${ }^{21}$ See id.

22 BArRy Eichengreen, The POPUlist Temptation: ECONOMIC Grievance ANI) POIITICAI. RIAACTION IN TIII: MODERN ERA, I (2018); Rodrik, supra note 4, at 16. ${ }^{23}$ See Heather Stewart \& Anushka Asthana, David Cameron Says His EU Campaign is Project Fact, Not Project Fear, The GuArdinn (Feb. 29, 2016), https://www.theguardian.com/politics/2016/feb/29/cameron-dismisses-claimsproject-fear-eu-remain-negative.
} 
consequence some set of voting citizens can be convinced to reject the "moral legitimacy" of the elite. 24

Trade economists Gene Grossman and Elhanan Helpman argue that populism is a specific form of "identity politics," such that voters" preferences over trade policy reflect both their economic self-interest as well as their concerns for the groups in society with whom they identify. ${ }^{25}$ From this they show how a dramatic rise in populism could lead to a substantive shift in a country's trade policy towards protectionism; these insights are specifically motivated by recent developments in the US. Their model consists of an economy with two types of worker, less-skilled and more-skilled, the latter accounting for a minority of the population. The economy produces both an exportcompeting and an import-competing good, the latter intensively using less-skilled workers. More skilled workers identify with and constitute the elite, while the less-skilled majority constitute the "working class." Members of either skill group may also identify with a group Grossman and Helpman describe as "the broad nation," characterized as capturing society's aversion to inequality. ${ }^{26}$ Finally, there are two political parties with different ideological stances, each setting a trade policy position in order to compete for votes. The authors then posit a "populist revolution" driven by a significant external event such as the China import shock which widens the income distribution. As a result, less-skilled workers no longer embrace "the broad nation," rejecting the legitimacy of the elites, and seeing the nation as synonymous with their type. The political-economic outcome is one where a political party running on a populist platform implements a discrete jump in the tariff rate imposed on the imported good. ${ }^{27}$

Before turning to the specific reasons for the US and UK adopting radical changes in their trade policies, it is useful to distinguish between right and left-wing populism. As noted by Rodrik, most current populist movements are in the right-wing camp. ${ }^{28}$ These movements focus on what Rodrik terms a "cultural cleavage" between the people and some outside group that represent a threat to the

\footnotetext{
${ }^{24}$ See JAN-WERnER MÜller, What is POPUliSM? 1-6 (2016).

${ }^{25}$ See Gene M. Grossman \& Elhanan Helpman, Identity Politics and Trade Policy

1-2 (Nat'l Bureau of Econ. Research, Working Paper No. 25348, 2018).

${ }^{26}$ See id. at 2.

${ }^{27}$ See id. at 3-4.

${ }^{28}$ See Rodrik, supra note 4, at 24.
} 
"popular will,",29 e.g., Donald Trump targeting Mexican immigrants and China, and UK supporters of leaving the EU targeting Eastern European immigrants and "unelected" bureaucrats in Brussels. ${ }^{30}$ The alternative left-wing version of populism revolves more around the idea that a wealthy elite control the economy at the expense of lower income groups, e.g., Syriza in Greece and Podemos in Spain. ${ }^{31}$ Political reality, of course, may shade this binary description, i.e., in the aftermath of the global financial meltdown, populist politicians chose to demonize bankers rather than focus on the technical causes of the crisis. In other words, it is easier for populists to offer a simple narrative that the "people" can relate to rather than discuss deeper concepts and policy solutions. ${ }^{32}$

\section{What Drove The US AND UK To ECONOMIC NATIONAliSm?}

The policy choices of the US starting a trade war, and the UK's exit from the EU, relate to different aspects of international economic theory even though, as we discuss below, both have common drivers. With respect to the US's imposition of tariffs, the economist's case against protection, which can be found in any undergraduate textbook on international trade, is at once both straightforward and nuanced. ${ }^{33}$ The standard view is that a country choosing protection will suffer a loss in national welfare as measured by a reduction in its gross domestic product (GDP). This follows from the fact that tariffs provide an incentive for resources to remain in inefficient import-competing sector(s) rather than being reallocated to more efficient exportcompeting sector(s), i.e., the classic economic gains from specialization are foregone. ${ }^{34}$ In addition, tariffs result in significant distributional effects between both consumers and firms, as well as consumers and the government, consumers paying a higher price for goods produced domestically as well as paying tariffs on imported goods. ${ }^{35}$ The net effect is that consumers end up losing more than domestic firms and the government exchequer gain, i.e., there is

\footnotetext{
29 Id.

${ }^{30}$ EICHENGRELN, supra note 22 , at 3.

${ }^{31}$ Rodrik, supra note 4, at 24.

32 Id.

${ }^{33}$ See JAMES R. MARKUSEN ET AL., INTERNATIONAL TRADE: THEORY AND

EVIDIENCE 246-49 (1995).

${ }^{34}$ See id. at 247.

35 Id. at 249.
} 
"deadweight" loss from protection. ${ }^{36}$ More recent economic analysis highlights additional costs to firms-given that tariffs may be applied to traded intermediate inputs such as automobile parts, with the increasing importance of value-chains, tariffs increase costs to firms who rely on these imported intermediate inputs. ${ }^{37}$

The exception to the standard economic case against the use of tariffs is when a country is "large" enough to affect its international terms of trade, i.e., the price it pays on the world market for imports relative to the world price of its exports. In the case previously outlined, the world price of imported goods does not change with the imposition of tariffs as the importing country is too "small" to exercise any market power. However, if an importing country is large enough, the world price of its imports will fall as the tariff is imposed. In this case, national economic welfare may increase, as the deadweight losses borne by consumers are more than compensated for by additional tariff revenue (subject to details relating to the elasticity of the export supply function). In other words, part of the cost of the tariff is now borne by exporting countries who face a lower world price for their exports, i.e., they suffer an international terms of trade loss. ${ }^{38}$ However, this case only applies if we assume that the exporting country facing the increase in tariffs does not retaliate with tariffs of its own. If it does, the tariff "war" that arises leads to economic losses for both countries in what has been denoted as a term of trade, "prisoners' dilemma." 39 To the extent that the trade war between the US and China is representative of this case, both countries, including the US as instigator of the trade war, face economic losses. We report on the significance of these economic losses later in Section V.

The issues relating to the UK's departure from the EU draw on a different aspect of international trade theory: specifically, the economics of FTAs. These agreements are aimed at increasing trade between partner countries (trade creation), but at the expense of less trade with non-partner countries (trade diversion); the essential point

\footnotetext{
${ }^{36}$ See id. at $281-84$.

${ }^{37}$ See Emily J. Blanchard, Trade Wars in the GVC Era, in TRADE WAR: THE Clash of ECONOMIC SYSTEMS ENDANGERING GLOBAL PROSPERITY 57.62 (Meredith A. Crowley ed., 2019) (ebook), https://voxeu.org/content/trade-warclash-economic-systems-threatening-global-prosperity.

${ }^{38}$ See MARKUSEN ET AL., supra note 33, 254-58.

${ }^{39}$ See Kyle BAgWell \& Robert W. STAIger, THE ECONOMiCS OF THE WORLD TRADING SYSTEM 1-3 (2002).
} 
is that FTAs are discriminatory. ${ }^{40}$ So unlike recent developments in US trade policy, which involve a departure from multilateral trading rules and the potential effect on US economic welfare as noted above, the impact of FTAs on economic welfare is much more ambiguous, i.e., it is uncertain for any given FTA whether the gains from trade creation outweigh the losses from trade diversion. ${ }^{41}$ In other words, there is no guarantee that economic welfare will increase and whether it does so will depend on several factors. However, as we note below in Section V, quantitative assessments of the UK's membership of the $\mathrm{EU}$ are almost unanimous in reporting the economic benefits of the UK's membership of the EU. This is not surprising: EU member countries are high-income, geographically close countries, with a high degree of integration of policies covering not just trade policies but policies relating to competition, agriculture, regions and social policy, and with a strong alignment of harmonized standards and regulations all of which foster trade between EU member countries. One of the challenges in assessing the impact of Brexit compared with the US trade war case is that the benchmark can differ in the UK case, i.e., the UK will be replacing one substantive trade agreement with alternative trading arrangements involving other FTAs, a reversal to WTO most favored nation (MFN) rules or even unilateral liberalization. ${ }^{42}$ However, as we detail below, given the degree of integration that the $\mathrm{UK}$ already has with the EU, economic welfare arising from Brexit is likely to decline.

If the current policy choices of both the US and UK are associated with potential reductions in their national economic welfare, what lies behind the drive towards economic nationalism? There are of course several candidates: a minimal social safety net in the US and economic austerity in the UK following the global financial crisis, immigration, the desire for national sovereignty, and globalization or, in the phrase associated with Rodrik, reference should be made to the notion of "hyper" globalization. "Hyper" or advanced

${ }^{40}$ See generally Scott L. Baier et al., Economic Determinants of Free Trade Agreements Revisited: Distinguishing Sources of Interdependence, 22 REV. INT'L. ECON. 31, 31-58 (2014); see generally Daniel C.K. Chow et al., The Revival of Economic Nationalism and the Global Trading System, 40 CARDOZO L. REV. 2133 , 2133-69 (2019).

${ }^{41}$ See Chow et al., supra note 40, at 2158-59.

${ }^{42}$ See Thomas Sampson, Brexit: The Economics of International Disintegration, 31

J. ECON. PERSPI:CTIVI:S 163, 164-67 (2017).

${ }^{43}$ See Rodrik, supra note 4, at 27. 
globalization is where the process of global market integration goes well beyond the removal of trade barriers to include, inter alia, rules on intellectual property rights, domestic regulations, and standards. Rodrik argues that in the later stages of globalization, the ratio of its redistributive effects to net economic gains is high, due to the efficiency effects of cutting tariffs diminishing over time as tariffs get lower, while the negative distributional effects continue to increase. ${ }^{44}$ In other words, as globalization advances, trade liberalization is less about increasing the size of the "economic pie" and more about redistribution. The potential correlation between globalization and increased income inequality certainly shows up in the data. For example, over the period 1979-2007, trade as a share of US GDP increased from 4.9 to 7.7 percent while at the same time the Gini coefficient measuring income inequality rose from 0.48 to 0.59 , trade integration and income inequality rising virtually in parallel in the 1990 s and 2000 s. $^{45}$

While recognizing the role of other factors, the focus in this article is on the links between globalization, populism and the desire for economic nationalism as experienced by the US and UK. However, to see the links, we need to look beyond the economic aggregates associated with the net benefits of trade and membership of FTAs as outlined above. As we discuss, for both countries it is the consequences of the rapid rise of China's presence on world markets that has caused significant distributional effects. These effects were typically concentrated in specific regions of each country that bore the brunt of the challenges associated with the rapid rise in China and which can be tied to voting patterns in the 2016 US presidential election and UK referendum on the decision to leave the EU. ${ }^{46}$

Before examining the empirical evidence on these specific distributional effects, it is important to place them in the appropriate economic context. International economists have consistently shown that trade allocates a country's relatively abundant resources to those

\footnotetext{
${ }^{44}$ See id. at 19-20.

${ }^{45}$ See Pol Antràs et al., Globalization, Inequality and Welfare, 108 J. INT'L ECON. 387, 387 (2017).

${ }^{46}$ See generally David Autor et al., Importing Political Polarization? The Electoral Consequences of Rising Trade Exposure (Nat'l Bureau of Econ. Research, Working Paper No. 22637, 2017); see Italo Colantone \& Piero Stanig, Global Competition and Brexit, 112 AM. POL. SCI. REV. 201, 201 (2018).
} 
sectors that intensively use such resources. ${ }^{47}$ Trade liberalization may cause job losses for less-skilled workers in the import-competing sector(s), but these losses are more than offset by job gains for moreskilled workers in the export-competing sector(s). ${ }^{48}$ Shifts in resources caused by trade maximize the value of the importing nation's GDP and raises the purchasing power of its consumers. ${ }^{49}$ This is formally known as the Heckscher-Ohlin theorem, ${ }^{50}$ familiar to all students of international economics. Note however that a key assumption of this model is that resources are mobile, and this mobility allows countries to maximize the gains from trade, but which also has implications for the income distribution effects, that may arise.

The corollary of the Heckscher-Ohlin theorem is that moreskilled workers used intensively in export-competing sectors benefit from trade, while less-skilled workers used intensively in importcompeting sectors are made worse off. In the US and UK, we might expect trade to benefit more-skilled workers such as aeronautical engineers employed by either Boeing or Airbus, while less-skilled workers in their respective steel industries would be worse off. This result, originally proposed by Stolper and Samuelson, implies that international trade can have a significant impact on the distribution of income. ${ }^{51}$ However, as noted above, the orthodox view is that benefits to winners (more-skilled workers and consumers) will outweigh costs to losers (less-skilled workers). Openness to trade therefore passes the benefit-cost test: the winners can in principle compensate the losers and still be better off. As noted earlier, whether or not such compensation in fact takes place is a matter of domestic policy, and in its absence provides an incentive for economic nationalism.

Prior to the 1990s, the flow of trade in goods was mostly between developed countries (the "North" versus developing

\footnotetext{
${ }^{47}$ See Ronald W. Jones \& J. Peter Neary, The Positive Theory of International Trade, 1 HANDBOOK OF INT'L. ECON. 15 (Ronald W. Jones \& Peter B. Kenen eds., 1984).

${ }^{48}$ See Jonathan Haskel et al., Globalization and US Wages: Modifying Classic

Theory to Explain Recent Facts, 26 J. ECON. PersipeCTIVES 119, 128-31 (2012).

${ }^{49}$ See MARkuSIN bi Al.., supra note 33, at 63-66.

${ }^{50}$ See Jones \& Neary, supra note 47, at 21 .

5I See generally Tariffs and Wages: An Inconvenient lota of Truth, TII: ECONOMIST (Aug. 6, 2016), https://www.economist.com/economics-brief/2016/ 08/06/aninconvenient-iota-of-truth.
} 
countries, the "South"). ${ }^{52}$ High-income countries accounted for 80 percent of world trade in $1985 .^{53}$ Specifically, countries with similar GDP/capita produced goods such as automobiles, constrained by economies of scale and the size of their own market, and then traded those goods with other high-income countries in a larger integrated market for similar but differentiated goods. ${ }^{54}$ The view among economists is that trade within these industries with an expanded international market not only resulted in consumers benefiting from a greater variety of goods, but that it also helped minimize the costs to "losers," as it is easier to reallocate resources within industries than to reallocate from one industry to another. ${ }^{55}$ This reduced the impact of trade on the distribution of income. ${ }^{56}$

With growth in trade accelerating after the Second World War, concerns were expressed in the $1980 \mathrm{~s}$ about growing income inequality in the US, reflected in the increasing gap between skilled and unskilled wages. ${ }^{57}$ Critics of globalization put part of the blame on growing imports from low-wage developing countries in the global South. ${ }^{58}$ However, empirical analysis published in the early to mid1990s concluded that the effects of North-South trade on US income inequality were very modest. ${ }^{59}$ By the start of the 2000 s, the consensus among trade economists was that trade was not a key contributing factor in either declining employment in the US manufacturing sector or rising income inequality. ${ }^{60}$ Economists argued that observed changes in the US labor market were mainly due to technological change in the manufacturing sector, which complemented moreskilled workers, thereby driving up skilled relative to unskilled

\footnotetext{
${ }^{52}$ See Gordon H. Hanson, The Rise of Middle Kingdoms: Emerging Economies in Global Trade, 26 J. ECON. PERSPECTIVES. 41, 42 (2012); Daniel C.K. Chow et al., A Legal and Economic Critique of President Trump's China Trade Policies, $79 \mathrm{U}$ PITT. L. REV. 207, 215 (2017).

${ }^{53}$ See Hanson, supra note 52.

${ }^{54}$ See id. at 48.

${ }^{55}$ See Paul R. Krugman, Intraindustry Specialization and the Gains from Trade, 89

J. POL. ECON. 959, 970 (1981).

${ }^{56}$ See id. at 971.

${ }^{57}$ See Paul R. Krugman, Trade and Wages, Reconsidered, BROOKINGS PAPERS ON ECON. ACTIVITY 103, 104 (2008).

${ }^{58}$ See id.

${ }^{59}$ See id.

${ }^{60}$ See David H. Autor, David Dorn \& Gordon H. Hanson, The China Shock:

Learning from Labor-Market Adjustment to Large Changes in Trade, 8 ANN. REV. ECON. 205, 207 (2016).
} 
wages. ${ }^{61}$ For example, technological change through automation has reduced demand for less-skilled assembly jobs in manufacturing, while raising productivity and wages of more-skilled labor.

At the same time that economists reached a consensus that technological change was the main factor causing loss of US manufacturing jobs, exports from "factory China" exploded. ${ }^{62}$ Chinese exports gave skeptics a reason to question whether technological change or sharply rising exports from China was the cause of negative impacts on less-skilled labor. ${ }^{63}$ Between 2000 and 2007, US import penetration by low-wage countries grew from 15 to 28 percent, China's share of this growth being 89 percent. $^{64}$ The value of US imports from China rose by 171 percent between 2000 and 2007, compared to growth in US exports to China of 150 percent. ${ }^{65}$ US manufacturing faced a significant increase in Chinese import competition without an offsetting increase in exports-a pattern shared by virtually all industrial sectors. ${ }^{66}$ This import shock was not unique to the US, with China's share of UK manufacturing imports rising from 1 to 8.6 percent over the period $1988-2007 .^{67}$

There is now a growing body of research examining the impact of the China import shock on US employment and other metrics. ${ }^{68}$ For example, Justin Pierce and David Schott have shown that US extension of permanent normal trade relations (PNTR) to China in 2000 was associated with a sharp drop in US manufacturing employment between 2000 and 2003, the effect being stronger in industries most affected by a reduction in uncertainty about tariff rates. ${ }^{69}$ Other researchers have found a link between the China import shock and a

${ }^{61}$ See Eli Berman et al., Implications of Skill-Biased Technological Change:

International Evidence, 113 Q. J. Econ. 1245, 1246-47 (1998).

${ }^{62}$ See Autor et al., supra note 60, at 208.

${ }^{63}$ See id.

${ }^{64}$ See Autor et al., supra note 3, at 2122.

${ }^{65}$ See id. at 2131.

${ }^{66}$ See Autor et al., supra note 60, at 212.

${ }^{67}$ See Colantone \& Stanig, supra note 3, at 202.

${ }^{68}$ See JUSTIN R. PIERCE \& PETER K. SCHOTT, The Cost of US Trade Liberalization with China, in TRADE WAR: THE ClASH OF ECONOMIC SYSTEMS ENDANGERING Gi.OBAI. ProsplerITY, 13-18 (Meredith A. Crowley, 2019) (ebook), https://voxeu.org/content/trade-war-clash-economic-systems-threatening-globalprosperity.

${ }^{69}$ See Justin R. Pierce \& Peter K. Schott, The Surprisingly Swift Decline of US Manufacturing Employment, 106 AM. ECON. Rlv. 1632, 1632-35 (2016). 
wider range of economic and social issues including crime rates, ${ }^{70}$ increases in household debt, ${ }^{71}$ declines in marriage rates, ${ }^{72}$ and increased deaths from drug overdoses. ${ }^{73}$

In the context of this article, the most significant insights into the domestic consequences of the China import shock are associated with David Autor and colleagues in a series of articles. ${ }^{74}$ Their work on the US measures the geographic exposure of labor markets across the US to the increase in imports from China. As already noted, the "shock" feature of Chinese imports relates to the rapid rise primarily in manufacturing imports from China since the mid-1990s. The rising international competitiveness of China has been associated with increased openness in China which has allowed Western firms to outsource production activities to China, and led to the relaxation of central planning, accession to the WTO in 2001 and possible manipulation of their exchange rate. ${ }^{75}$ Not only has the rise in China's competitiveness given rise to concerns about "unfair" trade, but the extent and speed of the rise in imports from China has forced considerable adjustment in importing countries with the resulting impact on regional labor markets in importing countries where manufacturing activities are located.

Key to identifying the impact on labor is the definition of a labor "market." Rather than assuming that, at least in the long-run (the time frame associated with the impact of trade in the Heckscher-Ohlin model discussed above), labor is mobile within national borders, the research of Autor et al. has focused on commuting zones, defined as "the distance workers would reasonably commute to work, with commuting zones being located all across the US." ${ }^{, 76}$ A key feature that

\footnotetext{
${ }^{70}$ See YI CHE \& XUN XU, The China Syndrome in US: Import Competition, Crime, and Government Transfer, MUNICH PERSONAL REPEC ARCHIVE PAPER 68135, 1-4, (2015), https://mpra.ub.uni-muenchen.de/68135/.

${ }^{71}$ See Jean-Nöel Barrot et al., Import Competition and Household Debt, FED. RESERVE BANK OF N.Y. STAFF REPORTS No. 821, 1-4, (2018).

${ }^{72}$ See David H. Autor et al., When Work Disappears: Manufacturing Decline and the Falling Marriage-Value of Men 1-2 (Nat'l Bureau of Econ. Research, Working Paper No. 23173, 2018).

${ }^{73}$ See Justin R. Pierce \& Peter K. Schott, Trade Liberalization and Mortality: Evidence from U.S. Counties 2 (Nat'l Bureau of Econ. Research, Working Paper No. 22849, 2016), https://doi.org/10.17016/FEDS.2016.094.

${ }^{74}$ See Autor et al., supra note 60 ; see also Autor et al., supra note 3.

${ }^{75}$ See Autor et al., supra note 60, at 211-15.

${ }^{76}$ See Autor et al., supra note 3, at 2122-23, 2132.
} 
arises from using commuting zones as a unit of measurement is that labor does not have a strong tendency to change commuting zones. In other words, labor is not as mobile as trade theory assumes.

Autor et al. then overlay the industrial structure of US commuting zones in order to gauge the impact of exposure these industries have to competition from Chinese imports. Since this matches the characterization of commuting zones, they are then able to assess the impact of the recent rise of China on local labor markets. ${ }^{77}$ Since labor does not have a strong tendency to move, the impact of Chinese imports is particularly strong across certain US states; wages fall dramatically, women withdraw from the workforce, there is an increase in demand for social benefits and disability allowances and when workers are re-engaged in the same commuting zone, re-hiring is at wages much lower than previous employment. ${ }^{78}$ This is the main feature of the China import shock. The impact is dramatically different depending on geography; typically southern and eastern states suffer while other states escape the impact of the rise of China given the differences in industrial structure. In sum, looking beyond the aggregate of "national" welfare, the impact of the rapid recent rise in globalization, and especially the growth of China, has had a significant effect on certain parts of the US.

However, the effect of globalization on the political environment in the US, manifested in economic nationalism, requires one more part to the story: how did these effects impact the polarization of US voting patterns? Autor et al. address this issue by extending their analysis of the China import shock to an examination of voting patterns across the US. ${ }^{79}$ Using detailed data on voting in congressional and presidential elections, they report two main results. First, while accounting for other determinants of voting patterns, e.g., education, age, white collar status etc., due to the dramatic rise in imports from China, voters were less likely to support moderate candidates of either main political party. There was a swing to either end of the political spectrum reflecting an increase in polarization in the US political environment. Second, in presidential elections, in the districts most exposed to competition from Chinese imports, the China import shock was reflected in an increase in support for Republican

\footnotetext{
${ }^{77}$ See id. at 2123.

${ }^{78}$ See id. at 2159.

${ }^{79}$ Autor et al., supra note 46.
} 
candidates. ${ }^{80}$ Although other factors may have contributed to the divisiveness of US politics in recent years, these authors have established a clear link between the impact of globalization and political outcomes that ties closely with the "America First" slogan and the targeting of tariffs by President Trump. As Autor et al. point out, both presidential candidates explicitly highlighted competition from China in their electoral campaigns, the results here suggesting that the competition from China favored the Republican candidate. In a followup paper, Autor et al. report results from a counterfactual analysis: if competition from China had not been as strong as it was in certain states that were less vulnerable to Chinese imports, the Democratic candidate might have won the Electoral College vote. ${ }^{81}$

Other research by Colantone and Stanig explores the issue of the China import shock, but in this case the focus is on the UK and the potential link with the Brexit referendum. ${ }^{82}$ As with the US, the UK experienced a sharp rise in imports from China; total imports from low income countries as a whole increased but the share of imports from non-China low income sources remained low, i.e., the increase in globalization was almost wholly due to the rise in imports from China ${ }^{83}$ In exploring the links between the rise in globalization and the 2016 referendum on Brexit, their analysis consisted of two main parts. First, they explored voting patterns in the referendum. Second, they investigated which regions in the UK were most exposed to the China import shock. ${ }^{84}$ The key question was, therefore, to what extent was the sharp increase in globalization and the impact it had on regions most exposed to globalization, or, more specifically, trade with low income countries, a contributory factor in the Brexit referendum while accounting for other factors?

In terms of the first issue, voting for Brexit was not evenly spread across the UK. In broad terms, "Vote Leave" was concentrated in the midlands, the northeastern parts of England and the southeast. "Vote Leave" had less support in London and the surrounding area,

\footnotetext{
${ }^{80}$ See id.

${ }^{81}$ See David Autor et al., A Note on the Effect of Rising Trade Exposure on the 2016 Presidential Election 1 (Mar. 2, 2017) (unpublished manuscript) (https:// economics.mit.edu/files/12418).

${ }^{82}$ See Colantone \& Stanig, supra note 3.

${ }^{83}$ See id. at 202.

${ }^{84}$ See id. at 201.
} 
Wales, and Scotland. ${ }^{85}$ With reference to the second issue, exposure to globalization was strongest in the midlands and the north of England. Although there was not a perfect overlap between the industrial structure and exposure to globalization and "Vote Leave," there was a sufficiently strong correlation to suggest that there is a potential relationship between the two. ${ }^{86}$

Using an econometric model relating voting patterns in the referendum with the regional impact of the China import shock, and controlling for other factors that capture the economic differences across regions in the UK, they confirm a strong link between globalization and the Brexit vote. ${ }^{87}$ They substantiate this with more micro-level evidence relating to individual voting patterns, i.e., accounting for level of education, age, worker status etc., and not just voting patterns at the regional level. The link between globalization and the vote to leave the EU holds up: the statistically strong relationship between Brexit and globalization is robust to controlling for a wide range of other factors at the regional or individual level that may also have influenced the desire to leave the EU. ${ }^{88}$

Colantone and Stanig also explore the possible influence between Brexit and another dimension of globalization, i.e., immigration. The inflow of immigrants mainly from the relatively new members of the EU was featured prominently in the run-up to the referendum. However, they fail to find a clear, strong relationship between Brexit and immigration despite the media focus on this alleged connection. To the extent they do find a relationship, it emerges only with respect to "new arrivals" from Eastern Europe rather than the total level of immigration or immigrant share of regional population. ${ }^{89}$ This is consistent with other studies on the labor market effects of immigration: to the extent that there is a relationship, it does not relate to total numbers of immigrants present in the UK or overall flows of immigrants; the links between immigration, labor market outcomes and Brexit is more nuanced than what either the British media or pro-Brexit campaigners have suggested.

\footnotetext{
${ }^{85}$ See Colantone \& Stanig, supra note 3, at 208.

${ }^{86}$ See id. at 209.

${ }^{87}$ See id. at 209-13.

${ }^{88}$ See id. at 213-15.

${ }^{89}$ See id. at 215-16.
} 
How does the rise in globalization associated with the China import shock translate into the rise in economic nationalism in the UK and Europe more broadly? Colantone and Stanig also address this issue by investigating the links in the rise in the "radical" right wing parties across European countries and tie this with the exposure to the China import shock and voting patterns. ${ }^{90}$ They set out the argument that the rise in globalization could be reflected in opposite swings in the political spectrum. Since globalization results in distributional effects, exposure to increased trade and the difficulties or high costs associated with dealing with the consequences could be reflected in increased electoral support for left-wing parties that may be associated with protectionism combined with increased government expenditure on social safety nets. Alternatively, electoral support for more radical right-wing parties may increase with increased nationalism, protectionism and an economically liberal, i.e., low-tax, domestic political agenda. ${ }^{91}$ As noted earlier, these are key features associated with economic nationalism.

To address this, Colantone and Stanig extend the data used to address the impact of the China import shock in the UK, to fifteen European countries. On the political side, they create an index of the political stances of parties competing in national elections across the fifteen countries where, at a more aggregate level, the political index relates to "nationalism," "nationalist autarky" and "radical right." a more disaggregate level, they produce an index ranging from the "protectionist left" and "protectionist right" through to a measure of economic nationalism reflecting political stances on free trade and isolationism, laissez-faire on domestic economic issues and a strong nationalist stance. ${ }^{93}$

The headline results show a strong relationship between the China import shock and nationalism and nationalist autarky and, overall, a rising share of electoral support for radical right parties. ${ }^{94}$ The more disaggregated results are the most informative: There are no statistically significant results relating the China import shock and electoral support for the protectionist left. The strongest statistical results relate to the rise of right-wing economic nationalism. ${ }^{95}$ These

\footnotetext{
${ }^{90}$ See Colantone \& Stanig, supra note 12 , at 937.

${ }^{91}$ See id. at $938-39$.

${ }^{92}$ See id. at $941-42$.

${ }^{93}$ See id. at $942-43$.

${ }^{94}$ See id. at $944-49$.

${ }^{95}$ See id. at $949-51$.
} 
results are robust to controls reflecting trade from other sources, such as intra-EU trade, and characteristics of the industry composition of the regions where the impact of globalization was most strongly exposed.

In sum, these results show a strong link between globalization and the recent rise in economic nationalism. By allowing for the possibility of voting for more protectionist trade policy but with the possibility of stronger domestic intervention to deal with distributional impacts, Colantone and Stanig provide important insights into the implications of globalization in recent years. ${ }^{96}$ It should also be noted that these results differ from those produced by Autor et al. relating to the US. ${ }^{97}$ Specifically, the latter show that there is a strong link between the rapid rise in globalization and political polarization, but the polarization involves a shift in voters' preferences to either end of the political spectrum; ${ }^{98}$ Colantone and Stanig show that the experience of the fifteen European countries goes more clearly in one direction. ${ }^{99}$

Before considering how economic nationalism as a policy framework has been expressed in the US and UK, one further question remains to be addressed. Specifically, given that many other factors can have an impact on income distribution, the demise of manufacturing, economic disparities across regions, and economic austerity more generally, why is the emphasis on the impact of globalization and economic nationalism and not, say, on the rise of technology replacing workers in the manufacturing sector and the impact of the global financial crisis? Di Tella and Rodrik have recently explored this issue. ${ }^{100}$ They conduct a large online survey in the US and consider a range of factors that may impact on labor demand across regions. These include (i) a demand shock, (ii) a labor-saving technology shock, (iii) "bad" management, (iv) outsourcing activities to another country, (v) imports from rich countries, and (vi) imports from low income countries. Different sources of shocks elicited desire for government action; for example, in response to a demand or

\footnotetext{
${ }^{96}$ See id.

${ }^{97}$ See Autor et al., supra note 46, at 42.

${ }^{98}$ See id. at 43.

${ }^{99}$ See Colantone \& Stanig, supra note 12, at 951.

${ }^{100}$ See generally Rafael Di Tella \& Dani Rodrik, Labor Market Shocks and the Demand for Trade Protection: Evidence from Online Surveys 1-37 (Nat'l Bureau of Econ. Research, Working Paper No. 25705, 2019).
} 
technology shock, there was a desire for government action either in the form of "transfers" or restricting imports. ${ }^{101}$ But in relation to the source of the shock relating to imports from low income countries, there was an overwhelming response in favor of government restricting imports and opposition to government transfers that would cushion the effects of globalization. ${ }^{102}$

In sum, even though there can be several factors that may cause difficulties for labor market adjustment, there is a strong "preference" for government action, and government action of a specific form, when labor market adjustment relates to globalization, particularly imports from countries that export goods which may compete directly with (declining) manufacturing sectors. These insights support the econometric results from Autor et al. reported above: When they account for other shocks that may have affected the demand for labor in the US, the strongest impact in terms of the resulting polarization in US politics related to the rise in imports from China. ${ }^{103}$ They rationalize this on the basis that the China import shock is likely to have been more concentrated which, in turn, was reflected in swings to the less moderate sections of the political spectrum and contributed more than these other factors to the net gains by the Republican presidential candidate. ${ }^{104}$

\section{ECONOMIC NATIONALISM: THE RESPONSE IN THE US AND THE PÓLITICAL VACUUM IN THE UK}

\section{A. US Trade War}

Since President Trump came into office, his administration has chosen to follow a radical departure from US trade policy as implemented in the post-war period. While the administration has targeted many countries, it is the progressive escalation of average tariffs against China that stand out and have been a consistent part of the President's political strategy to present a narrative that China has hurt the US through not "playing by the rules." Prior to China joining the WTO in 2001, the US implemented an average tariff against China

${ }^{101}$ See id. at 2-3.

${ }^{102}$ See id. at 2.

${ }^{103}$ See Autor et al., supra note 46, at 3.

${ }^{104}$ See Autor et al., supra note 46, at 4. 
of 38.6 percent, which fell to 3.1 percent after China's accession. ${ }^{105}$ In the first phase of the trade war, during 2018, average US tariffs against China increased to 12.4 percent, covering $\$ 250$ billion worth of Chinese imports. ${ }^{106}$ On May 10, 2019, when ongoing trade talks between the US and China broke down, average US tariffs were increased to 18.3 percent. ${ }^{107}$ More recently on August 1, 2019, the President announced that new tariffs would be implemented against an additional $\$ 300$ billion of imports from China, raising the average tariff rate to 21.5 percent, with the threat that these tariffs will increase to an average of 27.8 percent, covering 97 percent of US imports from China. ${ }^{108}$

Apart from its appeal to economic nationalism, is there any economic logic to what President Trump is doing in terms of initiating and escalating a trade war with China? In order to answer this question, it is important to understand the basic logic of the GATT/WTO. ${ }^{109}$ As noted previously, formation of the GATT in 1947 was recognition by the international community of the damage visited on the global economy by countries unilaterally raising tariffs during the inter-war period, i.e., the outcome of the terms of trade "prisoner's dilemma" noted in the previous section. The GATT/WTO can essentially be thought of as a cooperative game where countries commit to reducing their tariffs following the principles of reciprocity and nondiscrimination. Specifically, during rounds of multilateral trade negotiations the focus is on balancing tariff concessions by individual countries, and the agreed lower tariffs are then applied on a nondiscriminatory, MFN basis. ${ }^{110}$ If any country unilaterally raises its tariff(s), thereby reducing market access of a trading partner(s), the latter can retaliate by withdrawing an equivalent amount of market

${ }^{105}$ See Chad P. Bown \& Eva Zhang, Trump's Latest Trade War Escalation Will Push A verage Tariffs on China Above 20 Percent, PETERSON INST. FOR INT'L ECON.: PIIE CHARTS (August 6, 2019), https://www.piie.com/research/piiecharts/trumps-latest-trade-war-escalation-will-push-average-tariffs-china-above- 20. ${ }^{106}$ See Chad P. Bown \& Eva Zhang, Trump's 2019 Protection Could Push China Back to Smoot-Hawley Tariff Levels, PETTERSON INST. FOR INT'L. ECON.: TRADE \& INVESTMENT POLICY W ATCH, (May 14, 2019, 5:00 PM),

https://www.piie.com/blogs/trade-and-investment-policy-watch/trumps-2019-

protection-could-push-china-back-smoot-hawley.

${ }^{107}$ See id.

108 See Bown \& Zhang, supra note 105.

${ }^{109}$ See Chow, Sheldon \& McGuire, supra note 40, at 2141-46.

110 See Daniel C.K. Chow \& Ian Sheldon, Is Strict Reciprocity Required for Fair Trade?, 52 VAND. J. TRANSNAT'L L. 1, 33-38 (2019). 
access. ${ }^{111}$ In other words, the rules of the GATT/WTO seek to maintain the balance of concessions and avoid the use of highly punitive actions by countries. ${ }^{112}$

Analysis of President Trump's trade policy choices has typically interpreted them in terms of a zero-sum game, i.e., rather than generating mutual benefits in a positive-sum game, international trade is a game where economically, one country is a winner while the other must be a loser. ${ }^{113}$ However, there is an alternative explanation for these actions: the administration has chosen to move from "rulesbased" to "power-based" bargaining over tariffs as a means of dealing with what are termed "latecomers" to the GATT/WTO. ${ }^{114}$ In 2017, the US's average MFN tariff was 3.4 percent, which compared to China's average MFN tariff of 9.6 percent. ${ }^{115}$ Given this asymmetry, the US has little left to offer in terms of reciprocity, and instead it has resorted to unilaterally raising its tariffs against China in order to induce them to cut their tariffs.

The jury is currently out on this strategy: instead of cutting its tariffs in response to the US raising tariffs, China has retaliated in kind by raising its tariffs against the US, their average tariff reaching 18.1 percent by $2018,{ }^{116}$ and there is little prospect that the two countries will reach an agreement to halt the trade war anytime soon. ${ }^{17}$ In addition, there are many complex issues associated with China's behavior as a trading nation that go well beyond their average tariff levels, including, inter alia, forced technology transfer, theft of intellectual property, investment restrictions, and subsidies to stateowned enterprises (SOEs). ${ }^{118}$ A commonly held view is that rather than targeting China unilaterally with tariffs, the US should have sought a

\footnotetext{
${ }^{111}$ See Chow, Sheldon \& McGuire, supra note 40, at 2144-46.

${ }^{112}$ See generally Robert R. Staiger, International Rules and Institutions for Trade Policy, in HANDBOOK OF INT'L ECON. 1495 (Gene M. Grossman \& Kenneth Rogoff, 1995).

113 See Chow \& Sheldon, supra note 110 , at 10.

${ }^{114}$ See Mattoo \& Staiger, supra note 6, at 1.

${ }^{115}$ See Chad P. Bown, The 2018 US-China Trade Conflict After 40 Years of Special Protection 30 (Peterson Inst. for Int'l Econ., Working Paper No. 19-7, 2019).

${ }^{116}$ See id.

${ }^{117}$ See Charles Hankla, Will Trump's trade war with China ever end?, CONVERSATION (Aug. 5, 2019), https://theconversation.com/will-trumps-trade-warwith-china-ever-end-121405.

118 See generally WAYNE M. MORRISON, CONG. RESEARCH SERV., RL33536, CHINA-US TRADE ISSUES (2018).
} 
coalition with other developed countries such as the EU and Japan, in order to bring a comprehensive case against China at the WTO. ${ }^{19}$

\section{B. What Form Will Brexit Take?}

In contrast to the explicit actions exercised by the Trump administration with the imposition of tariffs, political parties in the UK have vacillated over what form Brexit should take. ${ }^{120}$ This has been complicated by the split in political opinion on the case for Brexit or the form it would take crossing intra-party lines. ${ }^{12}$ In large part, this reflects the referendum on the decision to leave the EU: the question asked was binary (remain or leave) but there was no consideration of what "leave" would mean. ${ }^{122}$ Although the UK government has since given formal notice of its wish to cease being a member of the EU, the widespread debate in the UK and the subsequent political impasse (including the resignation of Prime Minister Theresa May) has revolved around what actual form Brexit will take. ${ }^{123}$ The choice of what form relations with the EU will take following Brexit will determine not only the trading relations with the EU but also the capacity of the UK to form FTAs with other countries; retaining membership of the EU customs union which would facilitate trade between the UK and its former EU partners would constrain the nature of trade deals it may want to agree with other countries. In broad terms, the Brexit debate since the referendum has focused on a "hard" vs. a "soft" Brexit and, tied closely with this, how "national sovereignty" is exercised by the UK in its future trading arrangements. ${ }^{124}$

${ }^{119}$ See Robert Z. Lawrence, How the United States Should Confront China Without Threatening the Global Trading System 1-8 (Peterson Inst. for Int'l Econ., Working Paper No. 18-17, 2018).

${ }^{120}$ See Theodore Dalrymple, Dangerous Times in the UK: Thoughts on the Brexit Mess, City JOURNAL_EYE ON TuE News (Apr. 1, 2019), https://www.cityjournal.org/brexit.

${ }^{121}$ See Rafael Behr, Deal or No Deal, Both Labour and Tories will Split over Brexit, GUARDIAN (Feb. 12, 2019), https://www.theguardian.com/ commentisfree/2019/feb/12/deal-no-deal-labour-tories-brexit-may-corbyn.

${ }_{122}$ See David Allen Green, The Tale of the Brexit Referendum Question, FIN. TIMIS (Aug. 3, 2017), https://www.ft.com/content/b56b2b36-1835-37c6-8152b175cf077ae8.

${ }^{12.3}$ See Benjamin Mueller \& Stephen Castle, Theresa May's Resignation Throws a Fractured Brilain Into Further Turmoil, N. Y. TIMISS (May 24, 2019), https://www.nytimes.com/2019/05/24/world/europe/uk-brexit- theresa-may.html. ${ }_{124}$ J.P., How a Sofl Brexil Differs From a Hard One, ECONOMIST (June 25, 2018), https://www.economist.com/the-economist-explains/2018/06/25/how-a-soft-brexitdiffers-from-a-hard-one 
The "hard" and "soft" Brexit options relate not only to the potential implications for trade costs and the re-orientation of UK trade but also to political issues (particularly in regard to the free movement of labor) that may be more or less palatable to the UK government and public as the post-Brexit trade deal will encompass trade-offs if access to the EU Single Market is to be retained. It is important to bear in mind that, although trade issues are central to post-Brexit options and the ability to negotiate new trade deals, Brexit is also tied up with other issues that will determine what the divorce from the EU will entail.

"Hard" Brexit is what the most zealous "Brexiteers" would demand and is alternatively referred to as the "WTO option."125 A more extreme version of this would involve unilateral trade liberalization since the WTO option would only constrain the maximum level of tariffs that could be applied; there would be no constraint on the UK choosing to reduce tariffs to zero as long as the WTO principle of non-discrimination was applied. In the WTO case, the UK would be, in a policy sense, completely extricated from the EU and would apply MFN tariffs vis-à-vis all its trading partners. The UK would seek trade deals with any other country independently of the EU. At the same time, the UK would lose access to the EU Single Market. There would be no requirement to retain the principle of free movement of labor, though the UK financial sector would have no right of access in other EU Member States. However, given that the EU is the UK's major trading partner, this would have a significant impact on trade. The UK's exports to and imports from the EU would now be subject to tariffs and non-tariff barriers, as detailed above. Even if the UK retained the same (EU) regulatory and other aspects of harmonization that apply at present, the costs of trade could still rise due to, inter alia, customs checks, border controls and auditing of regulations to ensure compliance.

"Soft" Brexit comes in a variety of forms, but which are largely centered on retaining some degree of access to the EU Single Market. ${ }^{126}$ These "soft" Brexit options reflect relationships that other non-member countries have established with the EU. One version of this is the "Norway option" involving membership of the European Economic Area (EEA): ${ }^{127}$ Norway is not a member of the EU, can

${ }^{125}$ See id.
${ }^{126}$ See id.
${ }^{127}$ See Sampson, supra note 2, at 164-165. 
negotiate its own trading arrangements with non-EU countries but has access to the EU Single Market. However, compromises would be necessary to comply with this option: as part of the Single Market, there would still have to be free movement of labor and contributions to the EU budget would still be made. In addition, the UK would have no input into rulemaking at the EU level but still be subject to EU decisions. But the costs of UK's trade with the EU would still rise even with tariff-free access and harmonization with EU standards. Specifically, the "Norway option" would require rules of origin for exports to the EU given that Norway still has the capacity to form its own trade arrangements with non-EU countries. ${ }^{128}$

An alternative "soft" option is a bilateral deal, very similar to the agreement Switzerland has with the EU. ${ }^{129}$ This again involves free access to the EU market but with the quid pro quo of free movement of labor. While the UK would have the freedom to negotiate bilateral deals with non-EU countries and to opt in or out of EU programs on a case-by-case basis, the downsides of this option (at least as it applies to Switzerland) is that trade in services is excluded which would have implications for the UK financial sector and that there are still financial contributions to the EU budget.

Bespoke FTAs, such as the Canadian FTA with the EU, offer alternative forms of post-Brexit arrangements with the EU, but there may be limitations on what would be covered here. ${ }^{130}$ For example, in the Canadian-EU FTA, although market access for Canadian exports to the EU will increase, there are certain exclusions particularly in the agricultural and food sectors and services. ${ }^{131}$ Finally, there is the option to become a member of the European Free Trade Area (EFTA) which would involve free trade in goods with the EU, excluding services, but avoids commitments regarding free movement of labor

\footnotetext{
${ }^{128} V$ arious studies have highlighted the impact of rules of origin as representing an increase in trade costs. See, e.g., Paola Conconi et al., The Perverse Effect of Rules of Origin, VOX CEPR POLICY PORTAL. (Mar. 16, 2016), https://voxeu.org/article/perverse-effect-preferential-rules-origins.

${ }^{129}$ See Sampson, supra note 2, at 166.

${ }^{130}$ See id.

1.31 The EU-Canadian trade deal - the Comprehensive Economic and Trade Agreement (CETA) - came into force in September 2017. Tariffs across almost all tariff lines are fully eliminated. There are some exceptions that apply in the food and agricultural sectors, however. Some sectors have been identified as being sensitive where either the opening of the partner countries markets has been limited or where it has been excluded from the trade agreement (for example, poultry).
} 
and contributions to the EU budget. The UK would be subject to product standards set by the EU and, by not being a member of the customs union, it would incur border checks to ensure compliance with EU requirements.

The options between "soft" and "hard" Brexit, therefore, have revolved around trade costs that will apply to the UK following exit from the EU and will relate to the extent to which the UK and EU will compromise on wider issues. At one end, the range of "soft" Brexit options involve access to the EU Single Market; in this case, there would still be an increase in trade costs beyond what applies to UKEU trade at present though with the added complications of retaining the principle of free movement of labor in particular and continued financial contributions to the EU budget, both of which could have significant political ramifications in the UK. ${ }^{132}$ At the other end, "hard" Brexit gives the UK more sovereignty and avoids the political compromises associated with the softer options. But "hard" Brexit would involve the most significant increase in trade costs and a greater re-orientation of trade away from the EU. ${ }^{133}$

\section{Discussion}

Although the China import shock has been identified as a common theme in both the election of President Trump, and, also the $\mathrm{UK}$ referendum vote to leave the EU, the policy responses have clearly been quite different. In the case of the US, while the President did withdraw the US from the Trans-Pacific Partnership (TPP), a "mega"FTA, and his administration also renegotiated the North American Free Trade Agreement (NAFTA), the focus has been almost exclusively on targeting China with tariffs, progressively escalating to a full-blown trade war between the two countries. In contrast, the UK, while seeking to redefine its trading relationship with the EU, is also actively seeking to negotiate either new FTAs or FTAs to replace those that were negotiated on its behalf by the EU.

In other words, the US has followed a key tenet of economic nationalism: opposition to free trade and increased isolationism, which imposes costs on both the US and Chinese economies, as well as running the risk of undermining the multilateral trading system. By contrast, economic nationalism in the UK is not being expressed

\footnotetext{
${ }^{132}$ See Sampson, supra note 2, at 165-66.

${ }^{133}$ See id.
} 
through a desire to become more isolationist, but instead the UK government wishes to exert sovereignty over its own current and future trading relationships. While this may have a negative economic impact on the EU, it does not reflect an obvious threat to the global trading system as, even with a "no-deal" Brexit, the UK has signaled that it will abide by the rules of the WTO.

\section{THE Costs of ECONOMIC NATIONALISM}

\section{A. US Trade Policy}

Not surprisingly, given the height and breadth of the tariffs applied by the US against China in 2018 , some widely reported studies of the short-run economic impacts have already been published, notably Fajgelbaum et al., and Amiti, Redding and Weinstein. ${ }^{134}$ Without discussing the technical details, the former study quantifies the impact of the trade war on the US for 2018 as follows: first, US consumers and firms that import goods lost in aggregate $\$ 68.8$ billion due to higher, tariff-inclusive prices; second, due to changes in the US's international terms of trade, US exporting firms saw increased benefits of $\$ 23.0$ billion; and, third, US tariff revenue increased by $\$ 39.4$ billion. The net impact, which can be thought of as the "deadweight loss" of the trade war in 2018 sums to $-\$ 6.4$ billion. In other words, the short-run net effects were quite small at 0.03 percent of US GDP, but the re-distributional effects were substantial. ${ }^{135}$ The latter study reports a similar estimate of the "deadweight loss" to the US economy in 2018 of $-\$ 6.9$ billion. ${ }^{136}$

Interestingly, Fajgelbaum et al.'s empirical analysis also shows that if other countries, including China, had not retaliated against US imposition of tariffs, US losses would have been smaller at $-\$ 2.0$ billion due to larger terms of trade effects-precisely what the theory predicts. ${ }^{137}$ Importantly, this result also emphasizes the economic risks

\footnotetext{
${ }^{134}$ See Pablo D. Fajgelbaum et al., The Return to Protectionism, (Nat'l Bureau of Econ. Research, Working Paper No. 25638, 2019); see also Mary Amiti, Stephen J. Redding, \& David Weinstein, The Impact of the 20/8 Trade War on U.S. Prices and Welfare, (Ctr. for Econ. Pol'y Res., Discussion Paper No. 13564, 2019).

${ }^{135}$ See Fajgelbaum et al., supra note 134, at 3.

${ }^{136}$ See Mary Amiti, Stephen J. Redding, \& David Weinstein, The Impact of the 2018 Trade War on U.S. Prices and Welfare, 22 (Ctr. for Econ. Pol'y Res., Discussion Paper No. 13564, 2019).

${ }^{137}$ See Fajgelbaum et al., supra note 134, at 27.
} 
associated with the US having started a trade war, i.e., an additional loss of $\$ 4.4$ billion. In addition, once the regional effects of foreign tariff retaliation are explicitly accounted for, the empirical evidence suggests that workers in strong Republican counties have borne the brunt of the trade war so far. This follows from the fact that US tariffs raised the cost of imported imports in these counties, and because retaliation has disproportionately been targeted at the US agricultural sector, notably the 25 percent Chinese tariff on US soybean imports. ${ }^{138}$ There is also evidence that foreign tariffs were explicitly targeted at districts that supported Trump in 2016, and that such targeting has been moderately successful, with Republican candidates faring worse in the 2018 Midterm elections. ${ }^{139}$

Beyond the immediate economic effect of US trade policy, there is the broader issue of how it might impact the multilateral trading system. As noted in Section IV, the issue of China's trading practices is well-documented, but rather than seeking recourse through the WTO's dispute settlement mechanism, the US has deliberately chosen to proceed via "power-based" bargaining. Specifically, it appealed to the WTO's national security exception in imposing tariffs on imports of steel and aluminum, and it unilaterally implemented tariffs on $\$ 250$ billion of Chinese imports under Section 301 of the US Trade Act of 1974 after only an internal investigation by the Office of the United States Trade Representative (USTR). ${ }^{140}$

The concern here is that by switching from "rules-based" to "power-based" bargaining, the US is putting the future of the post-war trading system at risk. As noted previously, the MFN principle and reciprocity have been key to the functioning of the GATT/WTO, both acting as a constraint on exercise of bargaining power by a powerful country such as the US. ${ }^{141}$ Specifically, MFN dilutes bargaining power by ensuring that tariff commitments to either one country or a sub-set of countries in the GATT/WTO are then offered to all other

\footnotetext{
${ }^{138}$ See id. at 3.

${ }^{139}$ See Thiemo Fetzer \& Carlo Schwarz, Tariffs and Politics: Evidence form Trump's Trade Wars 5 (Ctr. for Econ. Res., Working Paper No. 13579, 2019). ${ }^{140}$ See Chad P. Brown, The 2018 Trade War and the End of Dispute Settlement as We Knew It, in TRADE WAR: THE CLASH OF ECONOMIC SYSTEMS ENDANGERING GlobAl Prosperity 21, 22 (Meredith A. Crowley, 2019) (ebook), https://voxeu.org/content/trade-war-clash-economic-systems-threatening-globalprosperity.

${ }^{141}$ See Mattoo \& Staiger, supra note 6, at 2.
} 
countries in the GATT/WTO, and at the same time reciprocity establishes the idea that there will be a balance of tariff concessions in any negotiating round of GATT/WTO. By committing to such a set of rules, the US has helped induce other weaker/smaller countries to successively lower their tariffs under GATT/WTO. ${ }^{142}$ With the US apparently abandoning these rules, it is following a "myopic logic," i.e., by using bargaining tariffs, the US ignores the possibility that other countries will resort to the same strategy, thereby undermining the multilateral trading system and depriving China in the future of a commitment mechanism when it eventually becomes the global economic superpower. ${ }^{143}$ In the long run, the absence of an effective "rules-based" system could prove very costly to the US and its trading partners. ${ }^{144}$

\section{B. The UK's Brexit Policy}

In the run-up to and following the outcome of the referendum on the UK's membership of the EU, many studies were produced to evaluate the potential impact on the UK. These studies originated from private organizations, the government and academia; what is notable is the almost unanimous consensus that leaving the EU would reduce economic welfare and potentially substantially, contingent on the form that Brexit could take. To trade economists, the direction of the impact is not surprising. There had been several econometric studies on how trade between EU member countries had increased: Carrere, using data on 130 countries over the period 1962 to 1996 , estimated that membership of the EU increased trade by 104 percent; ${ }^{145}$ Baier and Bergstrand estimated that EU membership increased intra-EU trade by over 92 percent $^{146}$ and Eicher et al. estimated the trade enhancing effect to be in the region of 50 percent. ${ }^{147}$ Given the trade linkages between the UK and the rest of the EU, it is not surprising that trade is

\footnotetext{
${ }^{142}$ See id. at 8.

143 See id. at $11-13$.

144 See id. at 6.

145 See Céline Carrère, Revisiting the Effects of Regional Trade Agreements on

Trade Flows with Proper Specification of the Gravity Model, 50 EUR. ECON. REV.

223, 234 (2006).

${ }^{146}$ See Scott L. Baier \& Jeffery H. Bergstrand, Do Free Trade Agreements Actually Increase Members' International Trade?, 71 J. INl'l ECON. 72, 83 (2007).

${ }^{147}$ See Theo S. Eicher et al., Trade Creation and Trade Diversion Revisited: Accounting for Model Uncerlainty and Natural Trading Partner Effects, $27 \mathrm{~J}$. APPLIEID ECONOMI:TRICS. 310, 296-321 (2012).
} 
expected to decline as a consequence of Brexit. But the extent of this decline will depend on what trading relationships the UK establishes with the EU in the future and, related to this, the nature of the UK's trade with the rest of the world whether this be via WTO rules or establishing new FTAs with other countries.

The most significant studies of the economic impact of Brexit were produced by the UK Treasury and Dinghra et al. ${ }^{148}$ Although common to both is the economic evaluation of some degree of UK sovereignty over trade policy, they differ from the recent studies of the impact of the US-China trade war summarized above. First, 'given the potential "structural" changes to the UK economy as the UK reorientates its trading relations with the EU and the rest of the world, the economic evaluation differentiates between the static and dynamic effects. ${ }^{149}$ The static effects relate essentially to the impact on trade, and foreign direct investment, that would arise from Brexit. The dynamic effects relate to the impact on productivity since, over the long-run, trade encourages competition and innovation and has potentially more substantive effect on UK national welfare. ${ }^{150}$ Sampson reports that the dynamic effects of openness can exceed the static trade effects by a factor of between 2 to $3 .{ }^{151}$

The second main difference relates to defining what the alternative to membership of the EU will be, i.e., a "soft" or "hard" Brexit. Even the softest form of Brexit could potentially entail losses: although a "soft" Brexit would retain close trade linkages between the UK and EU, trade costs would still increase. But there would be a more substantive rise in trade costs with a "hard" Brexit due to the imposition of WTO MFN tariffs on imports from the EU, and the increase in non-tariff measures that would also impact trade. Of course, WTO MFN tariffs do not restrict countries from applying lower tariffs that would apply to both EU countries and the rest of the

\footnotetext{
${ }^{148}$ See HM TREASURY, THE LONG TERM ECONOMIC IMPACT OF EU MEMBERSHIP AND THE ALTERNATIVES (2016); Swati Dhingra et al., The Costs and Benefits of Leaving the EU: Trade Effects, 92 ECON. POLICY 652 (2017).

${ }^{149}$ See id. at 653-56.

${ }^{150}$ See id. at 678-82.

${ }^{151}$ See Thomas Sampson, et al., The Economists for Brexit Predictions Are Inconsistent with the Basic Facts of International Trade, LONDON SCH. ECON. \& POL. SCI.: BREXIT? (Aug. 23, 2017), https://blogs.lse.ac.uk/ brexit/2017/08/23/economists-for-brexit-predictions-are-inconsistent-with-basicfacts-of-international-trade/.
} 
world. This scenario of unilateral liberalization was advocated by a pro-Brexit group known as the "Economists for Free Trade" and was the isolated exception insofar as it estimated the impact of Brexit (in this form) to be positive, although these gains were disputed in the assessment by Sampson et al. ${ }^{152}$

Arguably the most widely publicized assessment of the impact of Brexit was the UK Treasury report published in the run-up to the Referendum. ${ }^{153}$ Although produced by a UK government department, it received a negative reaction from leading members of the UK Conservative Party which, given its evaluation of significant negative impacts arising from Brexit was labelled as "project fear". ${ }^{154}$ In more detail, the estimates from the UK Treasury indicated a substantial negative impact of Brexit. The most immediate and obvious impact relates to the change in trade flows and the volume of trade as barrierfree trade no longer applies to UK exports and imports even under the "soft" Brexit option. The Treasury estimates that the UK's departure from the EU but retained access to the Single Market would reduce trade by around 9 percent. The WTO option, however, would reduce UK trade by between -17 and -24 percent. A negotiated FTA deal would reduce trade by between -14 and -19 percent. ${ }^{155}$

The impact on trade is the source of the significant welfare losses that arise from Brexit. With a "hard" Brexit, welfare is predicted to fall by 7.5 percent. ${ }^{156}$ The Treasury aimed to convey the significance of these effects by relating the impact to the cost at the household level; in 2015 terms, each household would be $£ 5,200$ worse off as a result of a "hard" Brexit. A "soft" Brexit would still involve substantial losses of between 3.8 to 6.2 percent of GDP (equivalent to between $£ 2,600$ and $-£ 4,300$ at the household level), the range dependent on the specific form a "soft" Brexit would take. ${ }^{157}$ To put these numbers in context, the data from the UK Office for National Statistics reports average household disposable income in 2015 at around $£ 28,000$. As

\footnotetext{
${ }^{152}$ See id. at 164.

${ }^{153}$ See HM TREASURY, supra note 148, at 128.

${ }^{154}$ See Joshua Mackenzie-Lawrie, The Treasury is the real threat to Brexit, THE

COMMENTATOR (Feb. 7, 2019),

http://www.thecommentator.com/article/7306/the_treasury_is_the_real_threat to brexit.

${ }^{155}$ See HM TRLASURY, supra note 148 , at 128.

${ }^{156}$ See id. at 138.

${ }^{157}$ See id.
} 
the estimates from the Treasury analysis show, even the 'softest' version of all, i.e., continued access to the EU Single Market, would still involve losses to the UK as the level of trade with EU Member States would fall; this is due to the impact of some non-tariff barriers, such as customs procedures and rules of origin issues, even if there was tariff-free access and harmonization of standards between the UK and the rest of the EU. ${ }^{158}$

More detailed assessment of the (static) trade effects are reported by Dhingra et al., using an alternative approach, to measuring the impact of Brexit. ${ }^{159}$ As with the UK Treasury assessment, the trade effects of a "soft" Brexit are lower than the "hard" Brexit case. There is a decrease in total trade of between -8 percent (for imports) and -9 percent (for exports), though trade with the EU falls by a considerably greater amount ( -25 percent for exports and -22 percent for imports). In the "hard" Brexit case, trade falls by around -16 to -17 percent with the reduction in trade with the EU being much more significant. ${ }^{160}$ These trade effects translate into substantive changes in welfare. In the "soft" Brexit case, welfare falls by -1.34 percent which translates (at 2015 levels) into a decrease in household income of $-£ 893$. These losses are almost doubled in the "hard" Brexit case, with a decrease in welfare of -2.66 percent, corresponding to a decrease in household level income of - $£ 1773 .{ }^{161}$ The most significant impact relates to being outside the EU as further integration develops with further harmonization across EU member countries and the removal of remaining non-tariff barriers. The "price" of missing out translates into a decline in welfare of -0.9 percent in the "soft" Brexit case to -1.6 percent in the "hard" Brexit case. ${ }^{162}$

The UK Treasury provided an updated assessment of the potential impact of Brexit in 2018. ${ }^{163}$ This updated assessment was motivated by two factors. One was a revised methodology to evaluate the impact of Brexit. Second, since the political debate had developed on what form a "soft" Brexit may take due to publication of the

\footnotetext{
${ }^{158}$ See id. at 85.

${ }^{159}$ Swati Dhingra et al., The Costs and Benefits of Leaving the EU: Trade Effects, 92 ECON. POLICY 652, 674 (2017).

${ }^{160}$ See id.

${ }^{161}$ See id. at 671-74.

${ }^{162}$ See id. at 671.

${ }^{163}$ See HM TREASURY, EU EXIT: LONG TERM ECONOMIC ANALYSIS (2018).
} 
Government's White Paper, ${ }^{164}$ this together with the revised methodology would provide a revised assessment of the potential impact. That said, the revised assessment did not alter the substance of the impact of Brexit. The "softest" form of Brexit would reduce UK welfare by 0.7 percent; a "hard" Brexit, or in the revised terminology since negotiations were already underway, a "no deal" outcome, welfare would decline by 7.6 percent. ${ }^{165}$

In sum, none of the main studies report a positive outcome for the UK following Brexit, whatever form it takes. Indeed, all report substantive negative consequences with damaging effects on the UK economy which translates into significant reductions in the income of average households. The effects come not only through static effects associated with reductions in (net) trade but also through dynamic effects associated with increases in productivity and innovation associated with openness. As discussed above, economic nationalism as expressed in the outcome of the referendum to leave the EU, Brexit is not per se associated with concerns about globalization (at least as far as trade is concerned) as the expectation is that the UK government will seek trade deals with other countries. But Brexit is certainly denying gravity: the UK will reduce its ties with its major trade partner and forego lower trade costs associated with the process of European integration. These effects may be ameliorated to some extent by a "soft" Brexit option. As such, the decision by the UK to limit its ties with the EU (its major trading partner for both exports and imports) to a greater or lesser extent will result in significant negative consequences; there is almost unanimous consensus among economists that this will be the case. The quantitative assessments emphasize the role of the different mechanisms, but all are clear in their overall message: the reduction in welfare for UK households will be potentially significant and long-lasting.

\section{Summary}

As we have discussed above, economic nationalism as expressed in the context of President Trump's tariffs on imports from China and the UK's decision to leave the EU, at face value, appear to be different. One is specifically anti-trade, the other apparently pro-

\footnotetext{
${ }^{164}$ See generally HM GOVIERNMI:NT, TIII: FUTURI: RIII.ATIONSIIIP BI:TWIIIN THE UNITIID KINGIDOM AND EUROPIIAN UNION (2018).

${ }^{165}$ See HM TRI:ASURY, supra note 163, at 51.
} 
trade insofar as "Brexiteers" aim to align the UK with current WTO MFN tariffs and to foster new trade agreements with non-EU countries, or in the case of most ardent "Brexiteers," promote unilateral trade liberalization. However, given the nature of the UK's current ties with the EU and the increase in trade that has resulted from EU membership and President Trump's trade war with the country that has brought about the most significant shift in the global economy in the last two decades, both cases of economic nationalism result in disintegration for the world economy. This dis-integration of currently established trading relationships is the source of the losses that arise in the economic assessments of both cases. Thus, while appearing to be different, both cases reduce the level of trade and, by extension, economic welfare.

\section{SUMmARY AND CONCLUSIONS}

The election of President Trump in November 2016, and the UK referendum vote in June 2016 to leave the EU have heralded actual and potential economic shocks to both the US, the UK, and the global economy. In the case of the US, the Administration's unilateral targeting of China with import tariffs has prompted retaliation by China, which in turn has prompted tit-for-tat retaliation by the US, pushing the two countries closer to an all-out trade war, with negative spillovers to the world economy. In the case of the UK, the referendum vote has resulted in a lengthy debate over the form that Brexit should take, with proposed trading arrangements ranging from a "soft" to a "hard" Brexit, each with its own expected negative economic consequences. As described in this article, the China import shock was a common factor to both events. The economic impact of the shock created conditions favorable to a populist and nationalist political response in both the US and the UK, the former focusing on explicitly protectionist policies designed to put "America first," the latter focusing on restoring UK political sovereignty and control over its own trade policies outside of the EU.

However, despite the common cause and nationalist flavor of both the US and UK responses, on one level, the responses are quite different. For the US, unilateral imposition of tariffs against China is precisely what the principle of economic nationalism would predict. By contrast, whichever Brexit outcome is eventually reached, the UK is not seeking to unilaterally raise tariffs against its trading partners: in the case of "soft" Brexit, it will get a continued, albeit less integrated trading relationship with the EU, while with a "hard" Brexit it will end 
up operating under WTO rules and at the same time seeking to negotiate new FTAs with other countries. In other words, the UK's Brexit policy, while a response to economic populism, is clearly not protectionist. On another level though, the policy choices of the US and UK are quite similar in the sense that both are seeking to withdraw from existing trade arrangements in a process that can be termed disintegration. The US has unilaterally flouted its multilateral obligations under the WTO, and withdrawn from the previously negotiated TPP, while the UK seeks to leave a highly integrated economic arrangement with the EU. As shown in this article, both choices either are having or will have significant economic consequences for their respective economies, as well as the global economy. 